\title{
Pilot Study of Eco-Physiological Pepper Responses to Starfish-Based Organic Soil Amendments in Open-Field and Greenhouse Cultivations
}

\author{
Hyun-Sug Choi
}

check for

updates

Citation: Choi, H.-S. Pilot Study of Eco-Physiological Pepper Responses to Starfish-Based Organic Soil

Amendments in Open-Field and Greenhouse Cultivations. Horticulturae 2021, 7, 344. https://doi.org/10.3390/ horticulturae7100344

Academic Editors: Michailidis Michail and Georgia Tanou

Received: 27 August 2021

Accepted: 17 September 2021

Published: 25 September 2021

Publisher's Note: MDPI stays neutral with regard to jurisdictional claims in published maps and institutional affiliations.

Copyright: (C) 2021 by the author. Licensee MDPI, Basel, Switzerland. This article is an open access article distributed under the terms and conditions of the Creative Commons Attribution (CC BY) license (https:// creativecommons.org/licenses/by/ $4.0 /)$.
Department of Horticulture, Daegu Catholic University, Gyeongsan-si 38430, Korea; hchoiuark@gmail.com

\begin{abstract}
This pilot study was conducted to compare eco-physiological responses to starfish (SF)treated red peppers (Capsicum annuum $\mathrm{L}$.) in organic open-field (OF) and greenhouse $(\mathrm{GH})$ cultivations in commercial farmhouses, South Korea in 2019. Treatments included starfish-liquid fertilizer (LF) applied in OF (SF-OF) and GH (SF-GH) plots, and SF + seaweed in OF (SFS-OF) and GH (SFS-GH). Weekly $\mathrm{pH}$ levels in SFS-LF were fluctuated for a 16-week storage period at room temperature due to having higher soluble salt levels than those of SF-LF. All experimental plots were ranged on soil $\mathrm{pH}$ between 7.1 and 7.4. SF- and SFS-GH plots resulted in increased soil electrical conductivity, organic matter, and increased concentrations of total nitrogen, phosphorous pentoxide, potassium oxide, and magnesium oxide, as well as exhibiting a richer and more diverse bacterial community. Leaf width and length and plant height increased in plants cultivated in GH, with low canopy width and stem diameter also observed to have increased. Total fruit yields were approximately two times higher for peppers cultivated in GH compared to OF cultivated peppers.
\end{abstract}

Keywords: liquid fertilizer; microbial biomass; nutrient; pepper; starfish

\section{Introduction}

Red peppers (Capsicum annuum L.) are an essential seasoning for all South Korean dishes and accounted for approximately $20 \%$ of the production volume and cultivation areas of vegetable commodities in 2017 [1]. However, net income rates have constantly been decreasing year on year, from $84.9 \%$ in 1980 to $66.7 \%$ in 2015 , given the approximate 10 times increase in operating costs for greenhouses $(\mathrm{GH})$ and global climate change affecting open-field (OF) cultivation in South Korea, having a humid, warm, East Asian monsoon climate and moderately acidic soil. Organic pepper production is an alternative way to achieve high nutritive fruit yield and fruit security without the use of synthetic inorganic fertilizers and pesticides [2]. This has provided higher premium prices and contributed to its expansion in developing countries through the use of recycled natural resources [3].

Organic peppers are cultivated in OF over a long season from spring to fall and in GH during the winter to produce year-round availability of fresh fruit, requiring additional fertilization [4]. A variety of natural sources extracted from plant and animal wastes have been extensively used on organic arable lands for additional fertilization, increasing nutrient availability and complexity of the farmland soil fauna community [5-8]. Populations of starfish (SF) have rapidly increased in recent years from rising temperatures in coastal areas of $S$. Korea and have been increasingly employed as biological fertilizer approved for use on organic fruit and vegetable farms in S. Korea, with little verification from the literature cited for the ecological sustainability of the practice of employing SF in OF and GH cultivations.

Soil organic matter (OM) and electrical conductivity (EC) were the key edaphic factors affecting soil bacterial ecology in GH cultivation and driving management strategies to improve bacterial diversity and fruit production [9]. Soil bacterial communities have a 
direct role in mineralization and microbial biomass turnover in the plant rhizosphere, shifting the cycling of nutrient availability and OM decomposition [10,11]. SF showed high total nitrogen (T-N) concentrations, but mineralization rates and amounts of nutrients released depended on the microbial biomass and micro-environments, which varied across $\mathrm{OF}$ and GH cultivations [12]. The hypothesis of this pilot study was that different SF sources would have affected eco-physiological pepper responses in OF and GH systems, which was compared for mineral nutrient concentrations, soil bacterial community, and fruit productivity of red peppers.

\section{Materials and Methods}

\subsection{Experiment Layout}

The pilot study consisted of two set trials, the pre-experiment and the main experiment. The pre-experiment was conducted at a university GH facility under controlled climate conditions to investigate the effects of SF and SFS on pepper performance.

\subsection{Treatment in Pre-Experiment}

The pre-experiment was initiated to investigate the effects of organic nutrient solutions of SF and SF + seaweed (SFS) on the performance of pepper plants under controlled conditions. The central hypothesis was that nutrient release from the SF and SFS, and their effects on pepper performance would be different from each other under controlled conditions. 'Shinhong' red pepper seedlings, typically cultivated in South Korea, were grown in a commercial potting substrate of $10 \times 30 \mathrm{~cm}$ density and treated with SF-LF and SFS-LF in a university GH facility for 60 days from May to July, maintaining a daily temperature between 15 and $25{ }^{\circ} \mathrm{C}$. Root and shoot length and stem diameter on each treated plant were respectively measured with a measurer and digital Vernier calipers. Leaf chlorophyll content in the broad spread of leaves was colorimetrically estimated using a hand-held SPAD-502 m (Minolta Co., Tokyo, Japan). Root and shoot dry weights (DW) were measured with an electronic scale, calculating the shoot:root ratio. The number of fruit was counted on each plant at harvest.

\subsection{Treatment in the Main Experiment}

The main experiment was conducted with red peppers cultivated under OF and plastic GH systems in organically certified private farmhouses, Taean-gun, South Korea $\left(37^{\circ} \mathrm{N}, 126^{\circ} \mathrm{E}\right)$ in 2019 . The regional climate resulted in a higher average daily temperature of $19.5^{\circ} \mathrm{C}$ and a lower amount of accumulated precipitation of $678.0 \mathrm{~mm}$ from April to October compared to those of the last 30 years from 1981 to 2010 with the annual average of $18.9^{\circ} \mathrm{C}$ and $1097.7 \mathrm{~mm}$ [13]. Manure compost and oil cake were applied along with the annual amount of nutrients recommended for the growth of pepper plants at basal fertilization in both the OF and GH systems [1]. Black woven plastic mulch covered the peppers to prevent invasions of weed and insect populations in both systems. 'Wonderful Guy' pepper plants in OF (typically cultivated in OF) and 'Super Bigarim' in GH (typically cultivated in $\mathrm{GH}$ ) were planted at a density of $40 \mathrm{~cm}$ between the plants and a density of $135 \mathrm{~cm}$ between plant rows on 23 February 2019. The pepper fruits were then harvested from July to October in OF and from July to December in GH.

Treatment included SF applied in OF (SF-OF) and GH (SF-GH) plots and SFS applied in the OF (SFS-OF) and GH (SFS-GH). SF-LF was manufactured as $50.4 \% \mathrm{SF}, 3.4 \%$ molasses, $0.2 \%$ effective microorganism (EM), $0.8 \%$ humus, and $45.2 \%$ water for 3 -year fermentation, with SFS-LF being composed of $40.3 \%$ SF, $10.1 \%$ seaweed, $3.4 \%$ molasses, $0.2 \%$ EM, $0.8 \%$ humus, and $45.2 \%$ water. One liter of LF per plant was applied weekly from 30 days after planting up to harvest with 250 times dilution, with foliar applied at 500 times dilution in turn, which was approximately $1.0 \mathrm{mg}$ of T-N received for each plant. Drip irrigation was turned on in $\mathrm{OF}$ and GH plots when precipitation was not received on the soil surface for three consecutive days. 


\subsection{Nutrient Analysis in the Main Experiment}

Essential mineral nutrients in the LF were analyzed according to Rural Development Administration (RDA) protocols of soil and plant analysis [14], including weekly $\mathrm{pH}$ and EC measurements during 14-week storage at room temperature using a $\mathrm{pH}$ meter (FIVEEAST FE20, Mettler Tonedo Co., Suzhou, China) and an EC meter (HI 2315 Conductivity Meter, Hanna Co., Seoul, Korea), respectively. T-N concentration in the LF was determined using a $\mathrm{CN}$ analyzer (Vario MAX CN, Elementar Co., Langenselbold, Germany), with an analysis of P concentration using a UV-visible spectrophotometer (UV-2450, Shimadzu, Tokyo, Japan), and exchangeable cations with an ICP-AES (Simultaneous ICP Spectrometer, SPECTRO Analytical Instruments GmbH Co., Kleve, Germany).

Soil samples were taken at a depth of 0 to $20 \mathrm{~cm}$ in June for soil nutrient analysis [14], and soil OM contents were estimated through oxidization via the Tyurin method [14]. Soil T-N and available $\mathrm{P}_{2} \mathrm{O}_{5}$ concentrations were analyzed with a CN analyzer (Vario MAX CN, Elementar Co., Langenselbold, Germany) and a spectrophotometer (UV-2450, Shimadzu, Tokyo, Japan) respectively, with analysis of exchangeable cations performed using an ICP-AES (Simultaneous ICP Spectrometer, SPECTRO Analytical Instruments GmbH Co., Kleve, Germany), including other essential micro-nutrients. Pepper leaves were randomly sampled in June, their leaf width and length measured, then air-dried in a dry-oven at $65^{\circ} \mathrm{C}$ for 7 days and ground in a blender with four mill blades (WDL-1, Wonder blender Co., Tokyo, Japan). The ground leaves were used to analyze T-N concentration using the Kjeldahl method, with $\mathrm{P}$ analysis using the Vanadate method, and $\mathrm{K}, \mathrm{Ca}$, and $\mathrm{Mg}$ analyzed using an ICP-AES (Simultaneous ICP Spectrometer, SPECTRO Analytical Instruments GmbH Co., Kleve, Germany).

\subsection{Bacterial Analysis in the Main Experiment}

Soil at depths of 0 to $20 \mathrm{~cm}$ were sampled in June, which was then used to extract bacterial DNA using FastDNA ${ }^{\circledR}$ Spin Kit (MP Biomedicals, Seoul, Korea) at an analysis center (Chunlab, Inc., Seoul, Korea) based on the manufacturer's instructions. The V3 hypervariable region of $16 \mathrm{~S}$ rRNA was amplified by PCR with barcoded fusion primers. The sequence data of bacterial 16S rRNA gene fragments were used to describe ACE, Chao1, operational taxonomic units (OTUs), and abundance of dominant bacterial phyla using the Mothur software package [15].

\subsection{Pepper Measurement in the Main Experiment}

A SPAD-502 portable chlorophyll meter (Minolta, Tokyo, Japan) and fluorometer (FluorPen P100, Photon System Inc., Drasov, Czech Republic) were used to determine the relative concentrations of chlorophyll and PS II activity, respectively, in leaves, in June. Canopy width, stem diameter, and plant height were then measured to assess plant growth among treated individuals. Total fruit yield per ha indicated the sum of accumulated fresh harvested fruit weight.

\subsection{Data Analysis}

Each treatment in each experiment was composed of three replications. Each dependent variable in this experiment was analyzed statistically using the general linear model procedure (PROC GLM) of SAS (Version 8.02; SAS Institute, Cary, NC, USA) to analyze the significant differences in all responses. Means were separated using a least significant differences test at $p<0.05$. Data over time are shown as means \pm standard errors.

\section{Results and Discussion}

\subsection{Pre-Experiment}

Weekly $\mathrm{pH}$ increased in both LF treatments for the first 5 weeks of room temperature storage but rapidly decreased in the SFS-LF-treated plots between 5 and 8 weeks of storage (Figure 1A). High organic compounds in the SFS-LF plots would have decomposed into small molecules, generating organic acid, nitrification processes, and hydrogen ions [16] as 
shown by high soluble salts contained in the SFS-LF as a marine sourced fertilizer compared to those of SF-LF (Figure 1B). Concentrations of T-N, P, K, Mg, and Cu were similar in both $\mathrm{LF}$, with high concentrations of Fe, Mn, Zn, and B observed in the SF-LF (Table 1). The concentrations of $\mathrm{Ca}$ and Na were much higher in the SFS-LF than those of SF-LF, attributed to it containing $10 \%$ of seaweed ingredients with high $\mathrm{Ca}$ and Na [17]. SFS-LF increased shoot length, total length, and shoot DW of the pepper seedlings compared to those of SF-LF (Table 2), which would have been influenced by high plant growth stimulants and polysaccharides supplied from seaweed extracts in the SFS-LF [8,17-19].

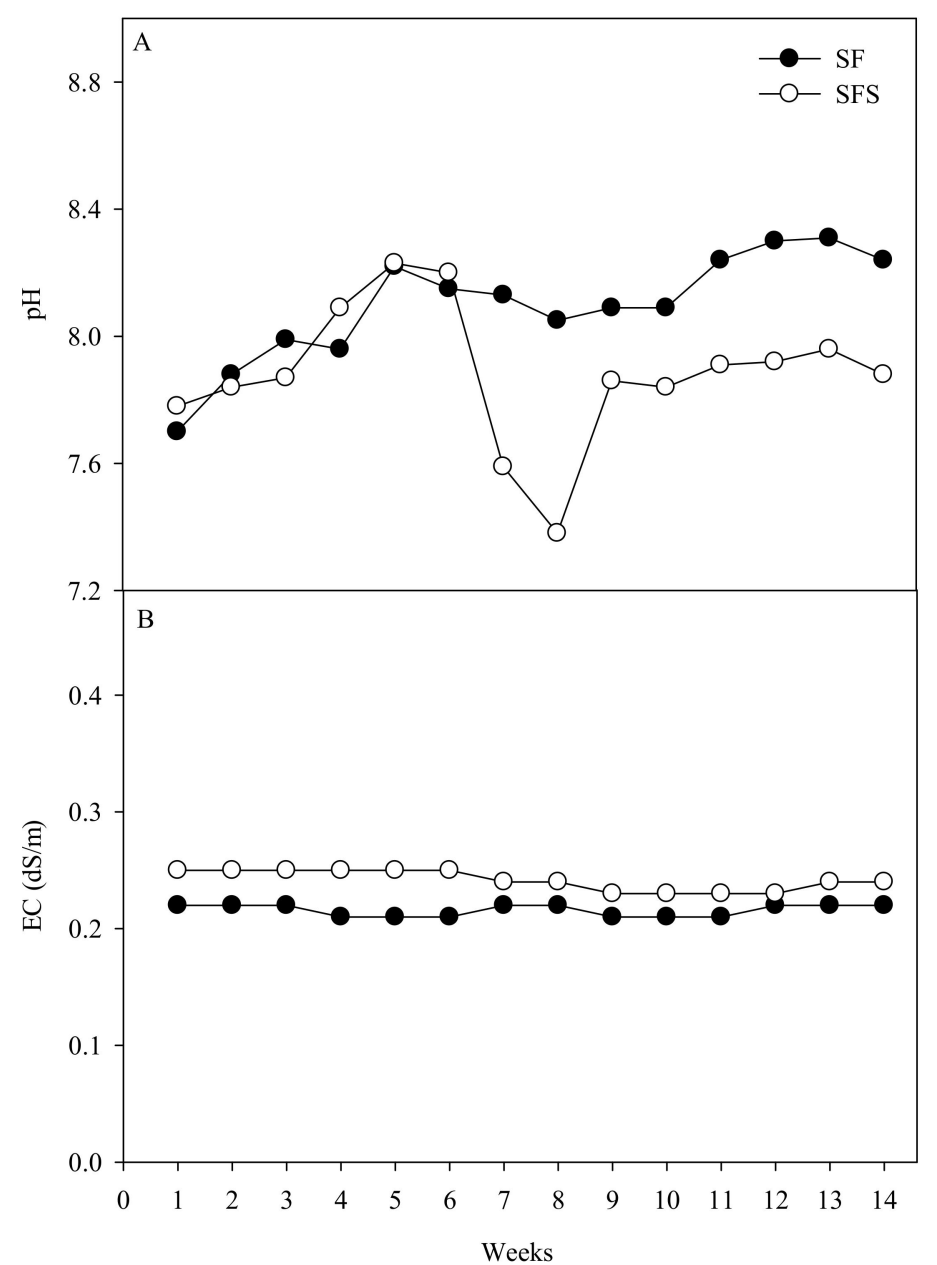

Figure 1. Weekly pH (Panel (A)) and EC (Panel (B)) in starfish (SF)- and starfish + seaweed (SFS)liquid fertilizers at weeks of storage.

Table 1. Nutrient concentrations in liquid fertilizers with starfish (SF)- and starfish + seaweed (SFS) resources used in an experimental plot.

\begin{tabular}{|c|c|c|c|c|c|c|c|c|c|c|c|}
\hline \multirow{2}{*}{ Treatment } & $\mathrm{T}-\mathrm{N}$ & $\mathbf{P}$ & $\mathbf{K}$ & $\mathrm{Ca}$ & $\mathrm{Mg}$ & $\mathrm{Fe}$ & Mn & $\mathrm{Zn}$ & $\mathrm{Cu}$ & B & $\mathrm{Na}$ \\
\hline & \multicolumn{11}{|c|}{$\left(\mathrm{mg} \mathrm{L}^{-1}\right)$} \\
\hline SF & 20 & 70 & 600 & 250 & 30 & 3.9 & 0.08 & 0.77 & 0.35 & 8.0 & 0.002 \\
\hline SFS & 20 & 70 & 610 & 380 & 30 & 2.6 & 0.06 & 0.49 & 0.35 & 7.4 & 568 \\
\hline Significance & ns & ns & ns & * & ns & * & * & * & ns & * & $* * *$ \\
\hline
\end{tabular}

$\mathrm{ns}$, not significantly different. ${ }^{*}, * *$ Significantly different mean values ( $\mathrm{n}=3$ liquid fertilizers) between treatments for each system at $p \leq 0.05$ and $p \leq 0.001$. 
Table 2. Growth of red pepper seedlings as affected by starfish (SF)- and starfish + seaweed (SFS)-liquid fertilizers.

\begin{tabular}{|c|c|c|c|c|c|c|c|c|c|}
\hline \multirow[t]{2}{*}{ Treatment } & $\begin{array}{c}\text { Shoot } \\
\text { Length }\end{array}$ & $\begin{array}{c}\text { Root } \\
\text { Length }\end{array}$ & $\begin{array}{c}\text { Total } \\
\text { Length }\end{array}$ & $\begin{array}{c}\text { Stem } \\
\text { Diameter }\end{array}$ & $\begin{array}{c}\text { Shoot (S) } \\
\text { DW }\end{array}$ & $\begin{array}{c}\text { Root (R) } \\
\text { DW }\end{array}$ & \multirow[t]{2}{*}{ S:R Ratio } & \multirow[t]{2}{*}{ SPAD } & \multirow[t]{2}{*}{ No. Fruit } \\
\hline & \multicolumn{4}{|c|}{$(\mathrm{cm})$} & \multicolumn{2}{|c|}{ (g) } & & & \\
\hline SF & 79.8 & 24.8 & 105 & 0.6 & 6.6 & 1.2 & 5.5 & 33.2 & 2.0 \\
\hline SFS & 88.5 & 24.0 & 113 & 0.6 & 8.1 & 1.2 & 6.6 & 34.8 & 1.8 \\
\hline Significance & * & ns & * & ns & $*$ & ns & $\mathrm{ns}$ & ns & ns \\
\hline
\end{tabular}

$\mathrm{ns}$, not significantly different. ${ }^{*}$ Significantly different mean values $(\mathrm{n}=3$ plants) between treatments for each system at $p \leq 0.05$.

\subsection{Nutrients and Bacterial Community in the Main Experiment}

Soil types in the SF-OF, SF-GH, SFS-OF, and SFS-GH plots were composed of sandy loam (sand $63.6 \%$, silt $32.4 \%$, and clay $4.0 \%$ ), loam (sand $49.5 \%$, silt $35.6 \%$, and clay $14.9 \%$ ), silt loam (sand $32.1 \%$, silt $50.9 \%$, and clay $17.0 \%$ ), and silt loam (sand $21.6 \%$, silt $67.0 \%$, and clay $11.4 \%$ ), respectively (data not presented). GH plots contained a lesser portion of sand particles than those GH plots, probably affecting salt accumulation and poor water and air circulation $[11,20]$.

All treated plots were ranged on soil with a pH between 7.1 and 7.4 (Table 3), indicating moderately high $\mathrm{pH}$ levels for optimum growth of pepper plants [21]. Soil EC was increased to $3.7 \mathrm{dS} \mathrm{m}^{-1}$ of SFS-GH plots, followed by SF-GH, SFS-OF, and SF-OF. Soil OM and concentrations of T-N, $\mathrm{P}_{2} \mathrm{O}_{5}, \mathrm{~K}_{2} \mathrm{O}$, and $\mathrm{MgO}$ were significantly higher in the $\mathrm{GH}$ plots, in particular on the SFS-GH than those values observed in OF plots. The concentration of $\mathrm{P}_{2} \mathrm{O}_{5}$ was increased to $1301 \mathrm{mg} \mathrm{kg}^{-1}$ in the SFS-GH plots and $768 \mathrm{mg} \mathrm{kg}^{-1}$ in the SF-GH plots. Continuous application of organic fertilizer would have contributed to high OM content and phosphate salt by reducing nutrient leaching and evaporation under the rooftop covering in the GH $[11,20]$. Exchangeable Ca concentration in the SFS plots was attributed to high Ca supplement in the SFS [8,17-19].

Table 3. Soil mineral nutrients as affected by starfish (SF)- and starfish + seaweed (SFS)-liquid fertilizers applied in open-field (OF) and greenhouse (GH) cultivated red peppers.

\begin{tabular}{|c|c|c|c|c|c|c|c|c|}
\hline \multirow{2}{*}{ Treatment } & \multirow{2}{*}{$\mathrm{pH}$} & \multirow{2}{*}{$\mathrm{EC}\left(\mathrm{dS} \mathrm{m}^{-1}\right)$} & OM & $\mathrm{T}-\mathrm{N}$ & $\mathbf{P}$ & $\mathbf{K}$ & $\mathrm{Ca}$ & $\mathrm{Mg}$ \\
\hline & & & \multicolumn{3}{|c|}{$\left(\mathrm{mg} \mathrm{kg}^{-1}\right)$} & \multicolumn{3}{|c|}{$\left(\mathrm{cmolc} \mathrm{kg}^{-1}\right)$} \\
\hline SF-OF & 7.3 & 0.9 & 14.1 & 8000 & 108 & 117 & 680 & 156 \\
\hline SF-GH & 7.2 & 2.1 & 27.1 & 1600 & 768 & 704 & 1160 & 288 \\
\hline Significance & ns & ns & $*$ & * & $*$ & * & ns & ns \\
\hline SFS-OF & 7.4 & 1.1 & 19.5 & 1100 & 545 & 782 & 2540 & 276 \\
\hline SFS-GH & 7.1 & 3.7 & 41.9 & 2400 & 1301 & 1369 & 2400 & 696 \\
\hline Significance & ns & $*$ & $*$ & * & $*$ & * & ns & * \\
\hline $\begin{array}{l}\text { Fertilizer } \\
\text { significance }\end{array}$ & ns & ns & ns & ns & * & ns & $* * *$ & ns \\
\hline Desired level & $6.0-7.0$ & $0.5-1.5$ & $20.0-30.0$ & - & $400-500$ & $274-313$ & $1000-1200$ & $180-240$ \\
\hline
\end{tabular}

ns, not significantly different. ${ }^{*}{ }^{* * *}$ Significantly different mean values $(\mathrm{n}=3$ soils) between treatments for each system at $p \leq 0.05$ and 0.01 , respectively. The desired levels were adopted from RDA (2010).

SF-OF plots showed decreasing numbers of OTUs and a lower richness estimate and diversity index with respect to the bacterial community compared to those of SF-GH plots (Table 4). The bacterial community was not significantly different between the SFS-OP and SFS-GH plots. GH plots were found to show high ACE (Figure 2A), Chao1 (Figure 2B), and the number of OUTs (Figure 2C) in the bacterial community compared to OF plots, indicating greater bacterial richness and diversity. EC levels mostly affected bacterial community structure, important in nutrient cycling and mineralization, which can be a primary estimator of the bacterial activity in the soil $[9,22,23]$. The phyla Planctomycetes and Firmicutes are favorable to high EC in soils with warm and humid conditions [9] and were present in considerable numbers in the GH plots applied with SF and SFS (Figure 3). The phylum Firmicutes mainly contains two classes of Clostridia and Bacillus capable of degrading large organic molecules to small molecules, converting $\mathrm{N}_{2}$ into ammonia, 
and stimulating nitrification and denitrification as part of the N-cycle [20]. Acidobacteria are known for a weak tolerance of salt accumulation in the soil $[9,20]$, which was not consistently observed in the $\mathrm{OF}$ and GH plots below saline soils of $4.0 \mathrm{dS} \mathrm{m}^{-1}[23,24]$.

Table 4. Soil bacterial community as affected by starfish (SF)- and starfish + seaweed (SFS)-liquid fertilizers applied in open-field (OF) and greenhouse (GH) cultivated red peppers.

\begin{tabular}{|c|c|c|c|c|c|}
\hline \multirow{2}{*}{ LF } & \multirow{2}{*}{ Number of OTUs } & \multirow{2}{*}{ Good's Coverage } & \multirow{2}{*}{$\begin{array}{l}\text { Richness Estimator } \\
\text { (Chao1) }\end{array}$} & \multicolumn{2}{|c|}{ Diversity Index } \\
\hline & & & & Shannon & Inverse Simpson \\
\hline SF-OF & 2132 & 95.7 & 2445 & 6.4 & 0.012 \\
\hline SF-GH & 3126 & 98.0 & 3265 & 6.9 & 0.003 \\
\hline Significance & $*$ & $*$ & $*$ & * & $*$ \\
\hline SFS-OF & 2564 & 97.6 & 2722 & 6.8 & 0.004 \\
\hline SFS-GH & 2589 & 97.1 & 2746 & 6.9 & 0.003 \\
\hline Significance & ns & ns & ns & ns & ns \\
\hline Fertilizer significance & ns & ns & ns & ns & ns \\
\hline
\end{tabular}

$\mathrm{ns}$, not significantly different. ${ }^{*}$ Significantly different mean values $(\mathrm{n}=3$ soils) between treatments for each system at $p \leq 0.05$.

ACE

N.S.(P=0.121)

A

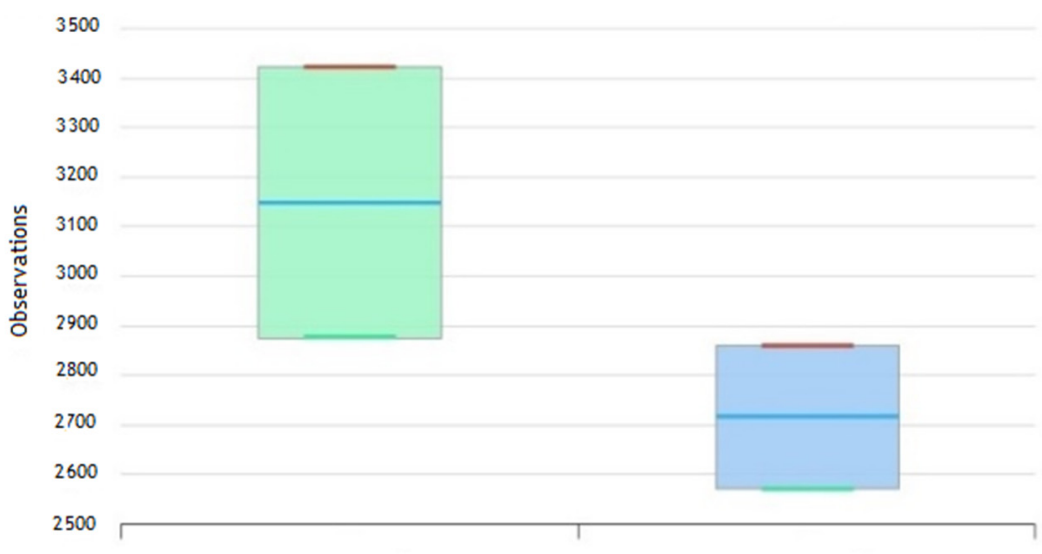

\section{Chao1}

N.S. $(P=0.121)$

B

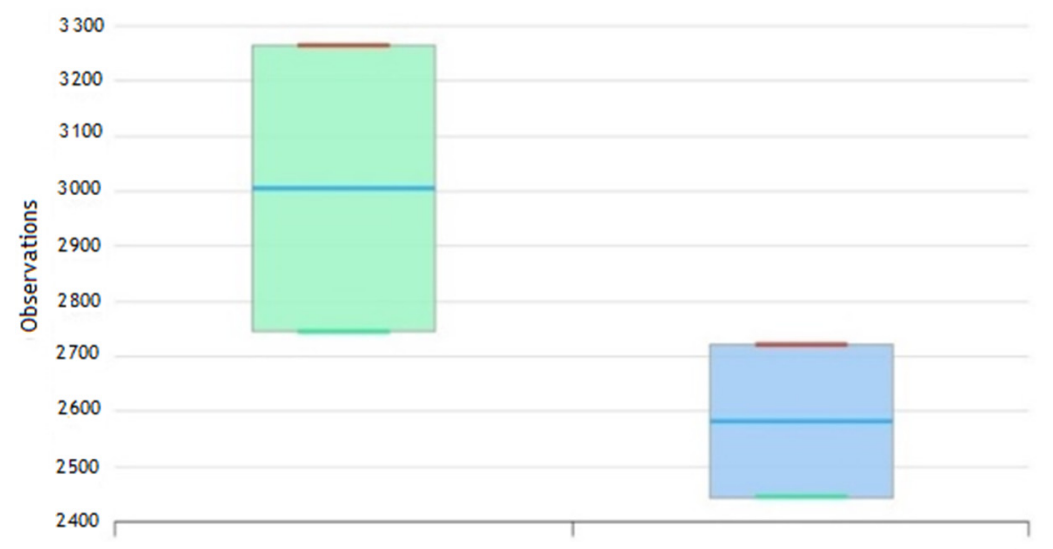

Figure 2. Cont. 
The number of OTUs found in MTP $\quad$ C

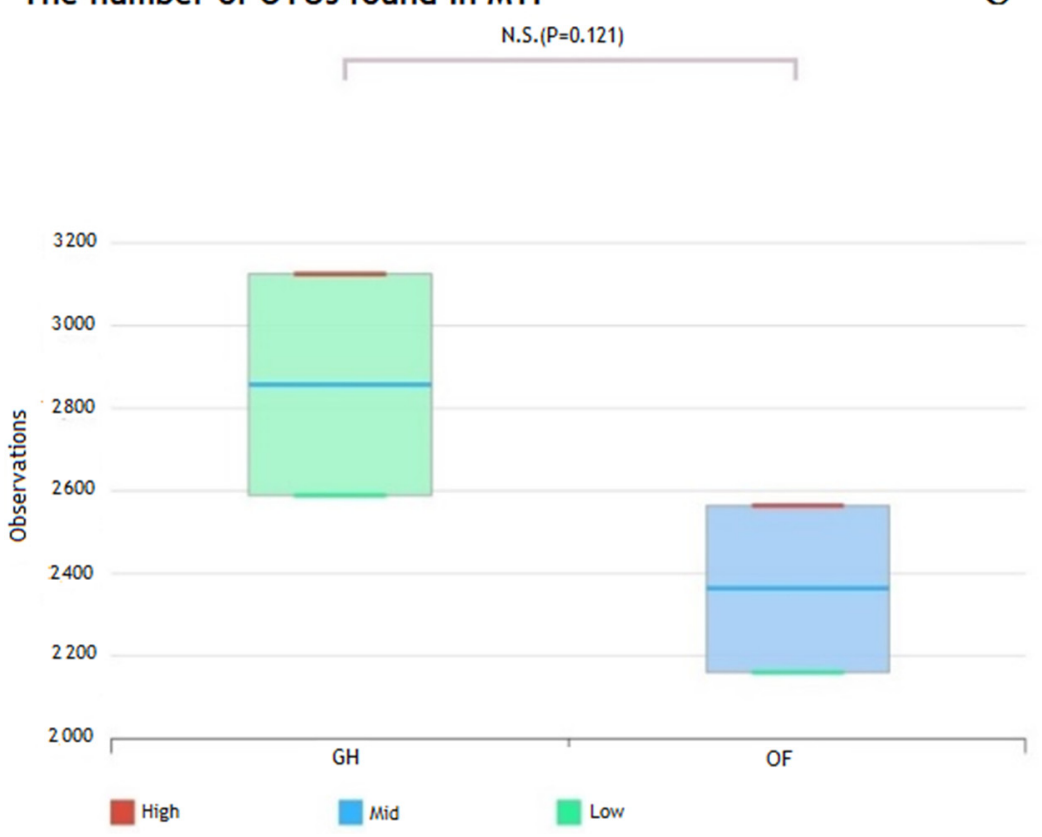

Figure 2. Bacterial diversity of ACE (Panel (A)) and Chao1 (Panel (B)) and number of operational taxonomic units (OTUs; Panel (C)) present in the soil in June as affected by open-field (OF) and greenhouse $(\mathrm{GH})$ cultivated red peppers. Bars represent the standard error of the mean.

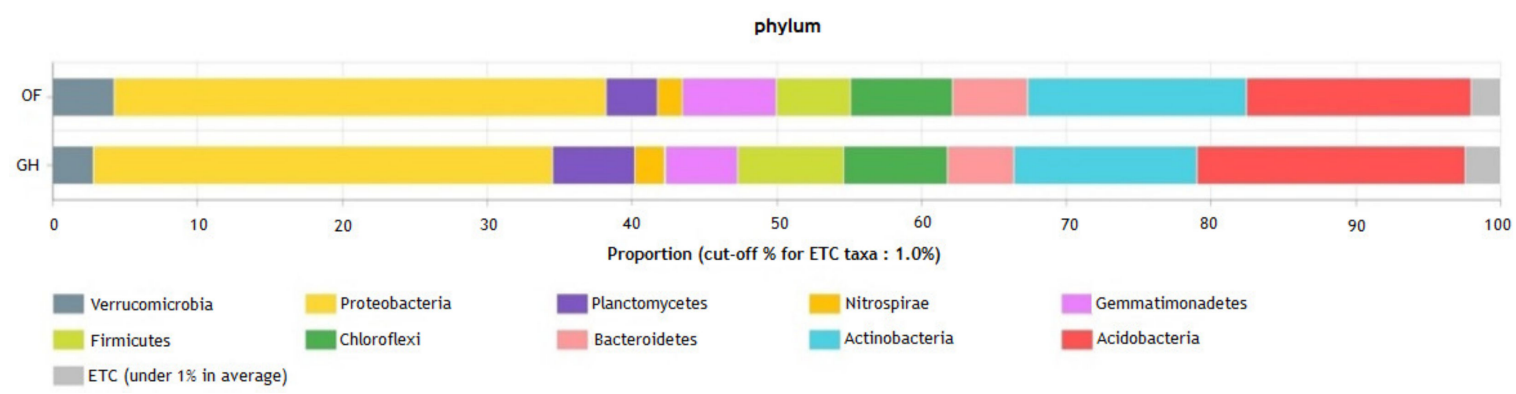

Figure 3. Relative abundance of the dominant bacterial phyla in soil on June as affected by open-field (OF) and greenhouse (GH) cultivated red peppers.

Foliar concentrations of macronutrients, except for $\mathrm{Mg}$, were not significantly different for plants grown in OF and GH plots, although OF plots showed reduced soil nutrients (Table 5). Concentrations of $\mathrm{P}, \mathrm{Zn}, \mathrm{Cu}$, and $\mathrm{B}$ tended to increase for plants cultivated in the OF plots. This would have been caused by the low transport of soil mineral nutrients into the plants under conditions of high relative humidity and salt accumulation in GH plots. Mineral nutrients in all the treated plants overall ranged between desired levels, except for $\mathrm{P}$ and $\mathrm{Mn}$, which, for sufficient growth of peppers [21], were increased to ameliorate concentrations of EC, OM, and other macronutrients of the soil. Excessive Mn uptake in plants is mostly associated with high Mn solubility occurring in low soil $\mathrm{pH}$ or with the application of acid-forming fertilizers [24,25]. Our experiment plots showed moderately high soil $\mathrm{pH}$ and were fertilized with alkaline-forming SF-LF and SFS-LF to avoid excessive Mn concentration in the plants, though this could have been induced through the monthly foliar application of the LF once every two weeks during the growing season. SFS-LF treatment significantly increased soil Ca concentration as supplementing with seaweed ingredients. 
Table 5. Plant mineral nutrients as affected by starfish (SF)- and starfish + seaweed (SFS)-liquid fertilizers applied in open-field (OF) and greenhouse (GH) cultivated red peppers.

\begin{tabular}{|c|c|c|c|c|c|c|c|c|c|c|}
\hline \multirow{2}{*}{ Treatment } & T-N & $\mathbf{P}$ & $\mathbf{K}$ & $\mathrm{Ca}$ & Mg & $\mathrm{Fe}$ & Mn & $\mathrm{Zn}$ & $\mathrm{Cu}$ & B \\
\hline & \multicolumn{10}{|c|}{$\left(\mathrm{mg} \mathrm{kg}^{-1}\right)$} \\
\hline SF-OF & 43,000 & 500 & 50,000 & 31,000 & 6000 & 201 & 1948 & 225 & 33 & 186 \\
\hline SF-GH & 43,000 & 400 & 50,000 & 34,000 & 9000 & 223 & 2108 & 62 & 21 & 125 \\
\hline Significance & ns & ns & ns & ns & $*$ & ns & ns & $*$ & $*$ & $*$ \\
\hline SFS-OF & 47,000 & 400 & 60,000 & 34,000 & 6000 & 147 & 1523 & 56 & 17 & 274 \\
\hline SFS-GH & 47,000 & 300 & 55,000 & 37,000 & 11,000 & 224 & 2446 & 47 & 9 & 252 \\
\hline Significance & ns & ns & ns & ns & $*$ & $*$ & $*$ & ns & $*$ & ns \\
\hline Fertilizer significance & $* * *$ & ns & $* *$ & $*$ & ns & ns & ns & ns & ns & $* *$ \\
\hline Desired level & $21,000-54,000$ & $300-400$ & $44,000-56,000$ & $11,000-27,000$ & $3000-9000$ & 55-174 & $16-53$ & $21-74$ & - & $17-68$ \\
\hline
\end{tabular}

ns, not significantly different. ${ }^{*}, * * * *$ Significantly different mean values $(\mathrm{n}=3$ plants) between treatments for each system at $p \leq 0.05$, 0.01, and 0.001. The desired levels were adopted from RDA (2010).

\subsection{Plant Growth in Main Experiment}

Leaf width and length were extended in plants cultivated under GH compared to those in OF (Table 6). However, canopy width and stem diameter were smaller in the GH plants, probably due to the elongation of plant height induced from apical dominance and fruit yield from increased foliar concentrations of $\mathrm{Mg}, \mathrm{Zn}, \mathrm{Cu}$, and $\mathrm{B}$. SPAD values, nondestructive estimates of foliar T-N and chlorophyll contents, and PS II values increased in the SFS-plants compared to those of SF-plants (data not presented) with significant increases in foliar concentrations of T-N, K, Ca, and B, presumably caused by supplementing with seaweed ingredients [8,17-19].

Table 6. Vegetative growth as affected by starfish (SF)- and starfish + seaweed (SFS)-liquid fertilizers applied in open-field (OF) and greenhouse (GH) cultivated red peppers.

\begin{tabular}{|c|c|c|c|c|c|}
\hline \multirow{3}{*}{ Treatment } & \multicolumn{2}{|c|}{ Leaf $(\mathrm{cm})$} & \multirow{2}{*}{ Canopy Width } & \multirow{2}{*}{ Stem Diameter } & \multirow{2}{*}{ Plant Height } \\
\hline & Width & Length & & & \\
\hline & & & $(\mathrm{cm})$ & & \\
\hline SF-OF & 4.8 & 9.4 & 80.8 & 2.2 & 120 \\
\hline SF-GH & 5.5 & 11.8 & 70.0 & 1.7 & 160 \\
\hline Significance & * & * & $*$ & * & * \\
\hline SFS-OF & 4.5 & 9.5 & 85.8 & 2.3 & 140 \\
\hline SFS-GH & 5.3 & 11.3 & 71.3 & 1.7 & 158 \\
\hline Significance & * & * & * & * & * \\
\hline Fertilizer significance & ns & ns & ns & ns & ns \\
\hline
\end{tabular}

* Significantly different mean values ( $\mathrm{n}=3$ plants) between treatments for each system at $p \leq 0.05$.

Total fruit yield increased approximately two times for peppers cultivated in GH compared with that of OF peppers (Figure 4), probably due to extended harvest duration, higher soil fertility, reduced water loss, and controlled external environmental factors in $\mathrm{GH}$ plots [12,26-28]. Pepper yields of various varieties increased from 50\% to $250 \%$ in GH plots with protected cultivation compared to those of $\mathrm{OF}$, as shown in other pepper studies [12,26]. OF plots experienced abrupt, climate change-induced, warmer and drier weather events during the growing season more frequently than those of the last 30-years [13,28], further lowering fruit productivity, regardless of LF nutrition sources. 


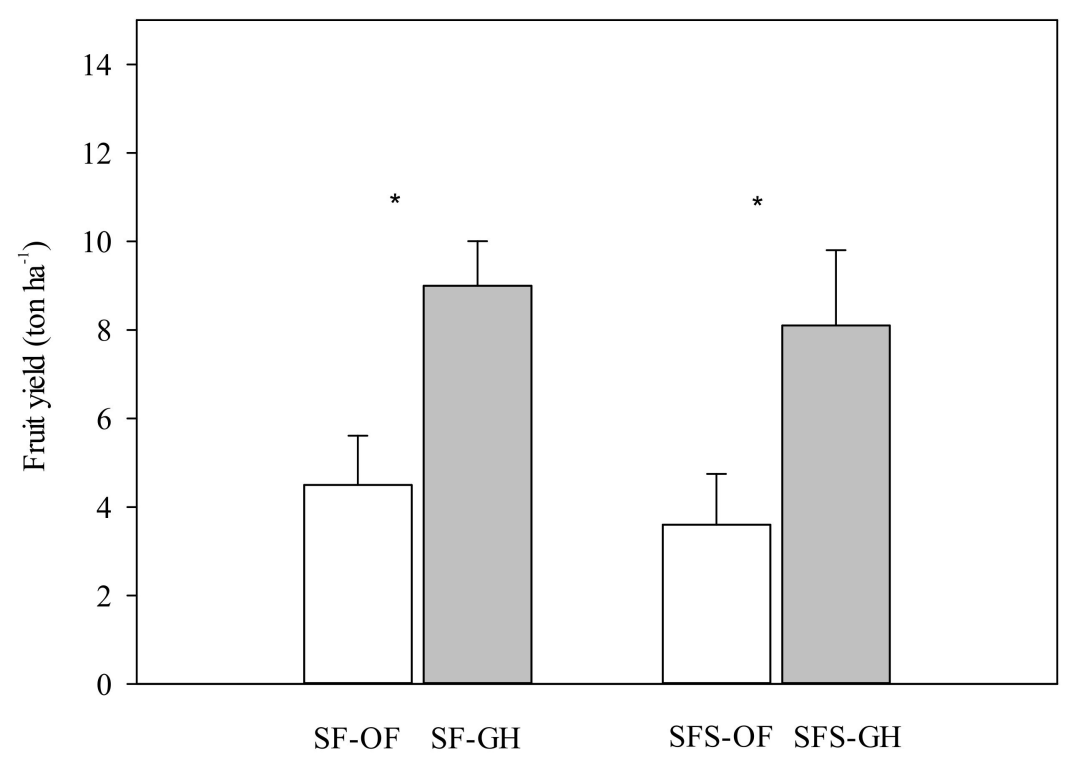

Figure 4. Fruit yield as affected by starfish (SF)- and starfish + seaweed (SFS)-liquid fertilizers applied in open-field (OF) and greenhouse (GH) cultivated red peppers. Bars represent the error of the mean. * significantly different mean values ( $\mathrm{n}=3$ plants) between treatments for each system at $p \leq 0.05$.

\section{Conclusions}

The eco-physiological pepper responses to SF and SFS were not overall significantly different in OF and GH plots, although SFS fertilizers increased some mineral nutrition in soil and plants. Moderately high soil EC and OM levels in the GH plots, regardless of SF and SFS, would have improved the composition of their soil bacterial community and improved nutrient cycling and ecological stability, largely enhancing fruit productivity. Although the use of starfish as raw material in the production of liquid fertilizers will be subject to government regulations in some countries, the recycling of marine by-products for SF or SFS for use as fertilizer would be recommended to organic farmers in developing countries. However, the pilot study might not be sounded due to the low sample size and absence of control plots, although the pre-experiment was initiated to investigate the effects of organic nutrient solutions under controlled conditions. The effects of SF sourcing and cultivation method on ecological stability and sustainable fruit production should be further studied in the long term to further understand the interaction effects between the external factors, including light, temperature, and water, and the internal factors of nutrient cycling and soil fauna.

Funding: Funding for this work was provided by the Rural Development Administration, Jeonju, Republic of Korea [grant number 01338806].

Acknowledgments: We greatly acknowledge supporting for this project from Daegu Catholic University.

Conflicts of Interest: The author declares no conflict of interest.

\section{References}

1. $\quad$ RDA. Pepper; Rural Development Administration: Jeonju, Korea, 2017.

2. Luttikholt, L.W.M. Principles of organic agriculture as formulated by the International Federation of Organic Agriculture Movements. Wagen. J. Life Sci. 2007, 54, 347-360. [CrossRef]

3. Badgley, C.; Moghtader, J.; Quintero, E.; Zakem, E.; Chappell, M.J.; Avilés-Vázquez, K.; Samulon, A.; Perfecto, I. Organic agriculture and the global food supply. Renew. Agric. Food. Syst. 2007, 22, 86-108. [CrossRef]

4. Aliyu, L. Effect of organic and mineral fertilizers on growth, yield and composition of pepper (Capsicum annuum L.). Biol. Agric. Hortic. 2000, 18, 29-36. [CrossRef]

5. Parr, J.F.; Papendick, R.I.; Colacicco, D. Recycling of organic wastes for a sustainable agriculture. Biol. Agric. Hortic. 1986, 3, 115-130. [CrossRef] 
6. Rosen, C.J.; Allan, D.L. Exploring the benefits of organic nutrient sources for crop production and quality. Horttechnology 2006, 17, 422-430. [CrossRef]

7. An, N.H.; Cho, Y.S.; Cho, J.R.; Kim, Y.K.; Lee, Y.; Jee, H.J.; Lee, S.M.; Park, K.L.; Lee, B.M. The survey of actual using conditions of farm-made liquid fertilizers for cultivating environment-friendly agricultural products. Korean J. Org. Agric. 2012, 20, $345-356$.

8. Hernández-Herrera, R.M.; Santacruz-Ruvalcaba, F.; Ruiz-López, M.A.; Norrie, J.; Hernández-Carmona, G. Effect of liquid seaweed extracts on growth of tomato seedlings (Solanum lycopersicum L.). J. Appl. Phycol. 2014, 26, 619-628. [CrossRef]

9. Kim, J.M.; Roh, A.S.; Choi, S.C.; Kim, E.J.; Choi, M.T.; Ahn, B.K.; Kim, S.K.; Lee, Y.H.; Joh, J.H.; Kang, S.S.; et al. Soil pH and electrical conductivity are key edaphic factors shaping bacterial communities of greenhouse soils in Korea. J. Microbiol. 2016, 54, 838-845. [CrossRef]

10. Arancon, N.Q.; Edwards, C.A.; Bierman, P.; Metzger, J.D.; Lucht, C. Effects of vermicomposts produced from cattle manure, food waste and paper waste on the growth and yield of peppers in the field. Pedobiologia 2005, 49, 297-306. [CrossRef]

11. Nair, A.; Ngouajio, M. Soil microbial biomass, functional microbial diversity, and nematode community structure as affected by cover crops and compost in an organic vegetable production system. Appl. Soil Ecol. 2012, 58, 45-55. [CrossRef]

12. Nkansah, G.O.; Norman, J.C.; Martey, A. Growth, yield and consumer acceptance of sweet pepper (Capsicum annuum L.) as influenced by open field and greenhouse production systems. J. Hortic. 2017, 4, 216.

13. KMA. Statistical Analysis of Climate; Korea Meteorological Administration: Seoul, Korea, 2019.

14. RDA. Comprehensive Test Room Analysis Manual; Rural Development Administration Publishers: Jeonju, Korea, 2017.

15. Schloss, P.D.; Westcott, S.L.; Ryabin, T.; Hall, J.R.; Hartmann, M.; Hollister, E.B.; Lesniewski, R.A.; Oakley, B.B.; Parks, D.H.; Robinson, C.J.; et al. Introducing mothur: Open-source, platform-independent, community supported software for describing and comparing microbial communities. Appl. Environ. Microbiol. 2009, 75, 7537-7541. [CrossRef] [PubMed]

16. Inbar, Y.; Chen, Y.; Hadar, Y. Humic substances formed during the composting of organic matter. Soil Sci. Soc. Am. J. 1990, 54, 1316-1323. [CrossRef]

17. Kuk, Y.I.; Yun, Y.B.; Jang, S.J.; Jeong, J.Y.; Kim, D.S.; Kim, S.S. Evaluation of tomato growth-promoting effect and mineral nutrient of farm-made liquid fertilizers. Korean J. Org. Agric. 2019, 27, 205-224.

18. Verkleij, F.N. Seaweed extracts in agriculture and horticulture: A review. Biol. Agric. Hortic. 1992, 8, 309-324. [CrossRef]

19. Battacharyya, D.; Babgohari, M.Z.; Rathor, P.; Prithiviraj, B. Seaweed extracts as biostimulants in horticulture. Sci. Hortic. 2015, 196, 39-48. [CrossRef]

20. Hou, J.; Li, M.; Mao, X.; Hao, Y.; Ding, J.; Liu, D.; Xi, B.; Liu, H. Response of microbial community of organic-matter-impoverished arable soil to long-term application of soil conditioner derived from dynamic rapid fermentation of food waste. PLoS ONE 2017, 12, e0175715. [CrossRef]

21. RDA. Criteria of Fertilizer Application in Crops; Rural Development Administration, Sammi Press: Wanju, Korea, 2011.

22. Han, G.; Lan, J.; Chen, Q.; Yu, C.; Bie, S. Response of soil microbial community to application of biochar in cotton soils with different continuous cropping years. Sci. Rep. 2017, 7, 101184. [CrossRef]

23. Choi, H.S. Effects of organic liquid fertilizers on biological activities and fruit productivity in open-field cherry tomato. Bragantia 2020, 79, 447-457. [CrossRef]

24. Weil, R.R.; Brady, N.C. The Nature and Properties of Soils; Person Publishers: Columbus, OH, USA, 2016.

25. El-Jaoual, T.; Cox, D.A. Manganese toxicity in plants. J. Plant Nutr. 1998, 21, 353-386. [CrossRef]

26. León, J.J.; Elías, J.L.; López, M.A.H.; López, A.M.G.; Ortiz, R.S.; García, L.F.E. Postharvest quality and shelf life of green pepper (Capsicum annuum L.) grown under open-field and greenhouse conditions. Idesia 2013, 31, 35-41. [CrossRef]

27. Yoon, Y.C.; Lee, K.H.; Suh, W.M. Water requirement of twisted sweet peppers in greenhouse. J. Korean Soc. Agric. Eng. 2000, 42, 59-66.

28. Bulgari, R.; Franzoni, G.; Ferrante, A. Biostimulants application in horticultural crops under abiotic stress conditions. Agronomy 2019, 9, 306. [CrossRef] 